\title{
Effects of Dietary Chromium Picolinate and Yeast Chromium on the Growth and Carcass Fat of Broilers
}

\author{
Yukihiro MOTOZONO ${ }^{1,2}$, Kazuhiro HATANO, \\ Norio SUGA WARA ${ }^{2}$ and Teru ISHIBASHI ${ }^{1}$ * \\ ${ }^{1}$ Graduate School of Science and Technology, Niigata University, \\ Niigata-shi 950-2102 \\ ${ }^{2}$ Feed Research Laboratories Nisshin Flour Milling Co., Ltd., \\ Nishinasuno-machi, Tochigi-ken 329-2763 \\ * Corresponding author
}

(Received August 12, 1997)

\begin{abstract}
Effects of two organic chromium(Cr), $\mathrm{Cr}$ picolinate and yeast $\mathrm{Cr}$, on the growth and carcass quality of broilers were studied. One-week-old female Arbor Acres broiler chicks were group-fed a commercial diet for 7 days. After then, they were divided into five dietary groups of 20 chicks each, and supplied the experimental diets containing $21.5 \%$ crude protein (CP) and 3.10 kcal ME/g for 14 days, and then $18.3 \% \mathrm{CP}$ and $3.20 \mathrm{kcal} \mathrm{ME} / \mathrm{g}$ for 21 days. To above two basal diets 0,200 or $400 \mathrm{ppb}$ of $\mathrm{Cr}$ derived from $\mathrm{Cr}$ picolinate and yeast $\mathrm{Cr}$ were added. Body weight gain and feed intake were recorded weekly. At the end of the trial, chicks were sacrificed to determine abdominal fat and contents of crude fat, CP and moisture in the skin-off breast meat and skin-on drumsticks meat. Feed intake and body weight gain tended to decrease in the all of Cr supplemented diet groups, and yeast $\mathrm{Cr}(400 \mathrm{ppb})$ significantly suppressed weight gain $(\mathrm{P}<$ 0.05). Yeast $\mathrm{Cr}$ tended to have a greater negative effect on the body weight gain and feed intake than $\mathrm{Cr}$ picolinate. The abdominal fat, $\mathrm{CP}$ and moisture in the skin-on drumsticks meat and skin-off breast meat were not influenced by the dietary $\mathrm{Cr}$ levels. The crude fat in the skin-on drumsticks meat was not affected by dietary $\mathrm{Cr}$ levels, but that in the skin-off breast meat decreased proportionally with increasing $\mathrm{Cr}$ levels.
\end{abstract}

Anim. Sci. Technol. (Jpn.) 69 (3) : 247-252, 1998

Key words : Broiler chicks, Chromium picolinate, Depression of carcass fat, Growth, Yeast chromium

Excess chromium ( $\mathrm{Cr}$, more than $300 \mathrm{ppm}$ ) is toxic for chicken $^{9)}$, and there are no reports observed $\mathrm{Cr}$ deficiency in poultry. Therefore, $\mathrm{Cr}$ is not listed as an essential mineral in the current version of NRC (1994) ${ }^{13)}$ and Japanese Feeding Standard for Poultry $(1997)^{1}$. Howev$\mathrm{er}$, it has been recognized that $\mathrm{Cr}$ reduces the fat accumulation without reducing the protein accumulation ${ }^{2,11,15)}$. Recently, it has been clarified that $\mathrm{Cr}$ elevates the activity of insulin in vivo ${ }^{11)}$, improves amino acid uptake by skel- etal muscle cells ${ }^{6}$, and connects with fat metabolism ${ }^{11)}$. The growth of female turkey chicks is improved by feeding a diet containing $\mathrm{Cr}^{15)}$. Addition of $\mathrm{Cr}$ to the diet resulted in the increased percentage of breast meat to total meat of turkeys ${ }^{2)}$. It has also been reported that $\mathrm{Cr}$ improves the immune function of beef cattle $^{5)}$ and milk cows ${ }^{4}$ raised under stressful conditions.

As a $\mathrm{Cr}$ source, organic $\mathrm{Cr}, \mathrm{Cr}$ picolinate has recently been attracting considerable atten- 
tion, because the carcass quality of pig is improved by the addition of $\mathrm{Cr}$ picolinate to the $\operatorname{die}^{10,12,14)}$. Mooney et al. ${ }^{12)}$ reported that the pig fed a diet containing $\mathrm{Cr}$ picolinate from the begining of the growth phase to the final growth yielded carcasses with a high muscle and a low fat. Although the fat content in poultry meat is less than in pork and beef, the abdominal and subcutaneous fat of broilers increase with advancing age. It is one of the most important problems to reduce these excess fat in broilers in the recent broiler industry. Until to date, a number of studies have been carried out concerning the effect of $\mathrm{Cr}$ picolinate on the quality of pig carcasses, but a few such studies have been published regarding broilers, in which the addition of $\mathrm{Cr}$ picolinate to the diet tended to reduce the carcass fat and increase the carcass protein of broilers ${ }^{7,817)}$. Yeast $\mathrm{Cr}$ was produced by fermentation with using brewer's yeast (Saccharomyces) and have ever been reported usefulness for beef cattle under stressful conditions ${ }^{5)}$, but no reports have been published on the effects of yeast $\mathrm{Cr}$ on the quality of broiler carcass.

Therefore, the present study was undertaken to reconfirm the effects of $\mathrm{Cr}$ picolinate and to confirm the effects of yeast $\mathrm{Cr}$ on the growth and carcass fat of broilers.

\section{Materials and Methods}

\section{Animals and experimental design}

One-day-old female Arbor Acres broiler chicks were obtained from a commercial hatchery, and group-fed a commercial starter diet until 7 days of age. Chicks were weighed and allotted into five experimental dietary groups of 20 chicks each with similar average body weights. The selected chicks were fed the five experimental diets containing 0,200 or $400 \mathrm{ppb}$ $\mathrm{Cr}$ derived from $\mathrm{Cr}$ picolinate and yeast $\mathrm{Cr}$ in wire cages in an environmentally controlled windowless house $\left(22 \pm 2^{\circ} \mathrm{C}\right.$ and lights on all day) for following 35 days from 8 to 42 days of age. Body weight and feed intake were recorded weekly throughout the experimental period. After measuring body weight of chicks at the end of the experiment, ten chicks were selected at random from each group, and killed by decapitation. Abdominal fat, skinoff breast meat (M. pectoralis superficialis) and skin-on drumsticks (mainly composed of $M$. trceps surae, $M$. tibialis anterior and $M$. fibularis longus) were collected.

Each meat sample was minced with a handoperated mincer to small pieces to determine moisture, crude fat using a Soxhlet extractor with diethyl ether and crude protein (CP) by the semi-micro Kjeldahl method.

\section{Diets}

Table 1 shows the composition of two basal diets used for 7 to 21 and 22 to 42 days of age. The former contained $21.5 \% \mathrm{CP}$ and $3.10 \mathrm{kcal}$ $\mathrm{ME} / \mathrm{g}$, and the latter contained $18.3 \% \mathrm{CP}$ and $3.20 \mathrm{kcal} \mathrm{ME} / \mathrm{g}$, respectively. The amounts of vitamins and minerals were adjusted to satisfy the requirements by NRC $(1994)^{13)}$. The amount of $\mathrm{Cr}$ derived from feedstuffs was negligible. As $\mathrm{Cr}$ sources, $\mathrm{Cr}$ picolinate (Prince Agri Products, Inc., USA) containing $400 \mathrm{mg}$ $\mathrm{Cr} / \mathrm{kg}$, and yeast $\mathrm{Cr}$ (Saccharomyces; Alltech, Inc., USA) containing $1,000 \mathrm{mg} \mathrm{Cr} / \mathrm{kg}$ were added to the both basal diets to be 0,200 , or 400 $\mathrm{ppb}$ as $\mathrm{Cr}$.

\section{Statistical analysis}

The data were subjected to analysis of variance. The significance of differences was tested using Fisher's least significant difference. Statements of significance are based on $\mathrm{P}<0.05$ unless otherwise stated.

\section{Results}

The performance of broilers is summarized in Table 2. Body weight gain significantly decreased in the yeast $\mathrm{Cr} 400 \mathrm{ppb}$ diet group compared with the control group. Feed intake tended to decrease in the all of $\mathrm{Cr}$ supplemented diet groups, except the $\mathrm{Cr}$ picolinate $\mathrm{Cr} 400 \mathrm{ppb}$ diet group. Body weight 
Dietary Chromium and Carcass Fat of Broilers

Table 1. Composition of basal diets ( $\mathrm{g} / \mathrm{kg}$ diet)

\begin{tabular}{|c|c|c|}
\hline Ingredients & $\begin{array}{c}\text { Starter } \\
\text { (1 to } 3 \text { weeks) }\end{array}$ & $\begin{array}{c}\text { Finisher } \\
\text { (3 to } 6 \text { weeks) }\end{array}$ \\
\hline Ground yellow corn & 465.8 & 470.1 \\
\hline Ground sorghum & 100.0 & 190.0 \\
\hline Wheat bran & 15.2 & 20.4 \\
\hline Soybean meal & 260.0 & 110.0 \\
\hline Canola meal & 24.0 & 55.0 \\
\hline Corn gluten meal & 9.0 & 10.0 \\
\hline Fish meal & 30.0 & 48.0 \\
\hline Meat bone meal & 41.0 & 45.0 \\
\hline Yellow grease & 40.0 & 43.0 \\
\hline Calcium carbonate & 6.0 & 3.0 \\
\hline Choline chloride & 1.5 & 1. 2 \\
\hline Dicalcium phosphate & 2.0 & - \\
\hline Sodium chloride & 1.9 & 1.6 \\
\hline DL-methionine & 1.3 & 0.3 \\
\hline $\mathrm{L}-\mathrm{lysine} \cdot \mathrm{HCl}$ & 0.3 & 0.4 \\
\hline Vitamin mineral mixture ${ }^{*}$ & 2.0 & 2.0 \\
\hline \multicolumn{3}{|l|}{ Calculated analysis } \\
\hline Crude protein (\%) & 21.5 & 18.3 \\
\hline Crude fat $(\%)$ & 7.1 & 7.8 \\
\hline Calcium (\%) & 0.9 & 0.8 \\
\hline Available phosphorus (\%) & 0.45 & 0.47 \\
\hline $\mathrm{ME}(\mathrm{kcal} / \mathrm{g})$ & 3. 10 & 3.20 \\
\hline Methionine (\%) & 0.50 & 0.39 \\
\hline Lysine (\%) & 1.17 & 0.96 \\
\hline
\end{tabular}

* Provides per kilogram of diet: (IU) vitamin A, 5,000; (ICU) vitamin $D_{3}, 1,000$; (mg) $\mathrm{d} 1-\alpha$-tocopherol acetate, 13 ; menadion, 0.8 ; thiamine nitrate, 2.3 ; riboflavin, 4 ; pyridoxine-HCl, 5 ; nicotinic acid amide, 36 ; D-pantothenic calcium, 12 ; folic acid, 0.56 ; cyanocobalamin, $0.01 ; \mathrm{d}$-biotin, $0.15 ; \mathrm{MnSO}_{4}, 170 ; \mathrm{FeSO}_{4}, 230$; $\mathrm{ZnSO}_{4}, 121 ; \mathrm{CuSO}_{4}, 22 ; \mathrm{Ca}\left(\mathrm{IO}_{3}\right)_{2}, 1.2$ and $\mathrm{MgCO}_{3}, 694$.

gain tended to be smaller in the $\mathrm{Cr}$ supplemented groups, and that in the yeast $\mathrm{Cr}$ groups was smaller compared to that in the $\mathrm{Cr}$ picolinate groups. Feed conversion ratio tended to increase in the $\mathrm{Cr}$ supplemented groups with increasing dietary $\mathrm{Cr}$ levels.

As shown in Table 3 , no significant differences were found in abdominal fat content nor abdominal fat ratio to body weight among the all groups. None of the parameters in the skin -on drumsticks meat differed significantly by dietary $\mathrm{Cr}$ levels. The crude fat content of skin-off breast meat decreased with increasing dietary $\mathrm{Cr}$ levels, but there were no differences caused by Cr sources. Although the moisture contents was not affected, the crude protein tended to increase with decreasing crude fat.

\section{Discussion}

When the diet containing $\mathrm{Cr}$ picolinate $(200$ $\mathrm{ppb}$ ) was given to the pigs from a low weight stage, weight gain and feed intake were significantly suppressed ${ }^{3)}$. In an earlier study on the effects of $\mathrm{Cr}$ on growth of turkey, addition of inorganic $\mathrm{Cr}$ chloride $\left(\mathrm{CrCl}_{3} \cdot 6 \mathrm{H}_{2} \mathrm{O}\right)$ to the diet resulted in the improvement of growth ${ }^{15)}$. In broilers it was reported that by addition of $\mathrm{Cr}$ picolinate to the diet the overall 


\section{MOTOZONO, HATANO, SUGAWARA and ISHIBASHI}

Table 2. Effects of dietary chromium ( $\mathrm{Cr}$ ) picolinate and yeast $\mathrm{Cr}$ on weight gain, feed intake, and feed conversion ratio of broilers

\begin{tabular}{|c|c|c|c|c|c|c|}
\hline \multirow{2}{*}{$\begin{array}{c}\text { Cr source } \\
\text { Dietary } \mathrm{Cr}(\mathrm{ppb})\end{array}$} & \multirow{2}{*}{$\begin{array}{c}\text { None } \\
0\end{array}$} & \multicolumn{2}{|c|}{ Cr picolinate } & \multicolumn{2}{|c|}{ Yeast $\mathrm{Cr}$} & \multirow{2}{*}{ Pooled SE } \\
\hline & & 200 & 400 & 200 & 400 & \\
\hline \multicolumn{7}{|l|}{ Body weight } \\
\hline Initial $(g)$ & 173 & 172 & 172 & 173 & 172 & 3 \\
\hline Final $(\mathrm{g})$ & $2.142^{a}$ & $2,075^{\mathrm{ab}}$ & $2,080^{\text {at }}$ & $2,078^{\mathrm{ab}}$ & $2,011^{b}$ & 31 \\
\hline \multicolumn{7}{|l|}{ Gain $(g)$} \\
\hline 7 to 21 days & $650^{a}$ & $638^{\text {as }}$ & $635^{\mathrm{ab}}$ & $645^{\text {ab }}$ & $615^{\mathrm{b}}$ & 10 \\
\hline 22 to 42 days & $1,319^{\mathrm{a}}$ & $1,265^{\mathrm{ab}}$ & $1,273^{\mathrm{ab}}$ & $1,260^{\mathrm{ab}}$ & $1,224^{b}$ & 22 \\
\hline 7 to 42 days & $1,969^{\mathrm{a}}$ & $1,903^{\mathrm{ab}}$ & $1,908^{32}$ & $1,905^{\mathrm{ab}}$ & $1,839^{b}$ & 29 \\
\hline \multicolumn{7}{|l|}{ Feed intake $(\mathrm{g})$} \\
\hline 7 to 21 days & 952 & 928 & 957 & 952 & 934 & 14 \\
\hline 22 to 42 days & 2,742 & 2,660 & 2,766 & 2,653 & 2,657 & 35 \\
\hline 7 to 42 days & 3,694 & 3,588 & 3,723 & 3,605 & 3,591 & 54 \\
\hline \multicolumn{7}{|c|}{ Feed conversion ratio $(\mathrm{g} / \mathrm{g})$} \\
\hline 7 to 21 days & 1. 46 & 1. 45 & 1. 51 & 1.48 & 1.52 & 0.02 \\
\hline 22 to 42 days & 2.08 & 2. 10 & 2.17 & 2.11 & 2.17 & 0.03 \\
\hline 7 to 42 days & 1.88 & 1.89 & 1.95 & 1.89 & 1.95 & 0.03 \\
\hline
\end{tabular}

Each value is means for 20 chicks.

${ }_{a-b}$ Means in the same row with different superscript letters are significantly different $(p<0.05)$.

Table 3. Effects of dietary chromium $(\mathrm{Cr})$ picolinate and yeast $\mathrm{Cr}$ on abdominal fat and moisture, crude protein, crude fat content in skin-off breast and skin-on drumstick of broilers

\begin{tabular}{|c|c|c|c|c|c|c|}
\hline \multirow{2}{*}{$\begin{array}{c}\text { Cr source } \\
\text { Dietary } \mathrm{Cr}(\mathrm{ppb})\end{array}$} & \multirow{2}{*}{$\begin{array}{c}\text { None } \\
0\end{array}$} & \multicolumn{2}{|c|}{$\mathrm{Cr}$ picolinate } & \multicolumn{2}{|c|}{ Yeast $\mathrm{Cr}$} & \multirow{2}{*}{ Pooled SE } \\
\hline & & 200 & 400 & 200 & 400 & \\
\hline Body weight $(\mathrm{g} / \mathrm{chick})$ & 2,140 & 2,181 & 2.134 & 2,157 & $2,1.20$ & 33 \\
\hline \multicolumn{7}{|l|}{ Abdominal fat content } \\
\hline (g/chick) & 55.8 & 61.6 & 56.0 & 64.3 & 52.3 & 4. 2 \\
\hline (\% of body weight) & 2.61 & 2.83 & 2.63 & 2.89 & 2.47 & 0.24 \\
\hline \multicolumn{7}{|l|}{ Skin off breast } \\
\hline Moisture (\%) & 74.2 & 74.0 & 73.9 & 74.1 & 74.1 & 0.4 \\
\hline Crude protein $(\%)$ & 23.2 & 23.7 & 23.8 & 23.7 & 23.8 & 0.3 \\
\hline Crude fat $(\%)$ & 1. $36^{\mathrm{B}}$ & $1.08^{b}$ & $1.01^{\mathrm{b}}$ & $1.07^{\mathrm{b}}$ & $0.97^{\mathrm{b}}$ & 0.09 \\
\hline \multicolumn{7}{|l|}{ Skin on drumstick } \\
\hline Moisture (\%) & 70.5 & 70.9 & 71.9 & 71.2 & 71.2 & 0.6 \\
\hline Crude protein (\%) & 18.0 & 17.4 & 17.7 & 17.9 & 17.7 & 0.2 \\
\hline Crude fat $(\%)$ & 10.4 & 10.3 & 9. 1 & 9.8 & 10.0 & 0.7 \\
\hline
\end{tabular}

Each value is means for 10 chicks selected randomly from 20 chicks.

${ }^{a-b}$ Means in the same row with different superscript letters are significantly different $(p<0.05)$.

growth nor nutrient utilization were not improved, but carcass fat tended to decrease and carcass protein tended to increase $e^{7,8,27)}$. In this study, the growth of broilers tended to be de- pressed by addition of $\mathrm{Cr}$, and especially depressed significantly on the yeast $\mathrm{Cr}(400 \mathrm{ppb})$ diet. Although the amount of yeast added to the yeast $\mathrm{Cr}(400 \mathrm{ppb})$ diet was only $0.04 \%$ of 
diet, some unknown factors contained in yeast might cause the depression of growth. The abdominal fat, which was used as an indicator fat accumulation, was unaffected by $\mathrm{Cr}$ supplementation. In the skin-off breast meat, the crude fat content was significantly lower in the broilers given diets containing $\mathrm{Cr}$ picolinate or yeast $\mathrm{Cr}$ than in the control group. The $\mathrm{CP}$ content tended to be increased by supplementation of $\mathrm{Cr}$ picolinate or yeast Cr. No differences of the crude fat, $\mathrm{CP}$ and moisture in the skin-on drumsticks were observed. Because much subcutaneous fat was contained in the skin-on drumsticks, they were not affected by dietary $\mathrm{Cr}$ levels. It might be possible that the depression of crude fat in the meat was masked by the large amount of subcutaneous fat.

In the present study, the addition of $\mathrm{Cr}$ picolinate or yeast $\mathrm{Cr}$ to the diet of broiler chicks suppressed fat accumulation in the breast meat. Mooney et al. ${ }^{12)}$ examined the carcass of pigs fed a diet containing $\mathrm{Cr}$ picolinate, and found that no difference in subcutaneous fat content between pigs fed the diets with or without $\mathrm{Cr}$, but fat content in the carcasses which pigs fed diet with $\mathrm{Cr}$ was smaller. They attributed this difference to the depression of fat in muscles cells and intermuscular fat following the ingestion of $\mathrm{Cr}$, and suggested the possibility that $\mathrm{Cr}$ enhances glucose or amino acid uptake by muscle cells ${ }^{12}$. The depression of fat accumulation in the skin -off breast meat in present study corroborated their conclusion. The data were not presented here, the $\mathrm{Cr}$ contents in the liver and skin-off breast meat ( $M$. pectoralis superficialis) of chicks fed the $400 \mathrm{ppb} \mathrm{Cr}$ diet were less than 0.3 ppm, the lowest value detected by diphenylcarbazide spectrophotometric method ${ }^{16)}$.

Whether or not there is a commercial merit of addition of $\mathrm{Cr}$ to the broiler diet depends on the future study, especially on the strain of chicken or the environmental condition to which chicks are exposed should be in- vestigated.

\section{References}

1) Agriculture, Forestry and Fisheries Research Council Secretariat. Japanese Feeding Stan. dard for Poultry. Central Assoc. Livestock Ind. Tokyo. 1997.

2) Anderson RA, Bryden NA, Polansky MM, Richard MP. Chromium supplementation of turkeys : Effects on tissue chromium. J. Agric. Food Chem., 37 : 131-143. 1989.

3) Boleman SL, Boleman SJ, Binder TD, Southern LL, Ward TL, Pontif JE, Pike MM. Effect of chromium picolinate on growth, body composition, and tissue accretion in pigs. J. Anim. Sci., 73 : 2033-2042. 1995.

4) Burton JL, Mallad BA, Mowat DN. Effects of Supplemental chromium on immune responses of periparturient and early lactation dairy cows. J. Anim. Sci., 71 : 1532-1539. 1993.

5) Chang $X$, Mowat DN. Supplemental chromium for stressed and growing feecer calves. J. Anim. Sci., 70 : 559-565. 1992.

6) Evans GW, Bowman TD. Chromium picolinate increases membrane fluidity and rate of insulin internalization. J. Inorg. Biochem., $46: 243-$ 250. 1992

7) Kim SW, Han IK, Choi YJ, Kim YH, Shin IS, Chae BJ. Effects of chromium picolinate on growth performance, carcass composition and serum traits of broilers fed dietary different levels of crude protein. Asia-Australian J. Anim. Sci., $8: 463-470.1995$.

8) Kim YH, Han IK, Choi YJ, Shin IS, Chae BJ, Kang TH. Effects of dietary levels of chromium picolinate on growth performance, carcass quality and serum traits in broiler chicks. Asia -Australian J. Anim. Sci., 9 : 341-347. 1996.

9) Kunishisa $Y$, Yamane $T$, Tanaka T, Fukuda I, Nishikawa T. Effect of dietary chromium on the performance of chicks. Jpn. Poult. Sci., 3 : 10-14. 1966.

10) Lindemann $\mathrm{MD}$, Wood CM, Harper $\mathrm{AF}$, Kornegay ET, Anderson RA. Dietary chromium picolinate additions improve gain : feed and carcass characteristics in growing-finishing pigs and increase litter size in reproducing sows. J. Anim. Sci., 73 : 457-465. 1995.

11) Mertz $W$. Chromium in human nutrition. J. Nutr., 123 : 626-633. 1993.

12) Mooney KW, Cromwell GL. Effects of dietary chromium picolinate supplementation on 


\title{
MOTOZONO, HATANO, SUGAWARA and ISHIBASHI
}

growth, carcass characteristics, and accretion rates of carcass tissues in growing-finishing swine. J. Anim. Sci., 73 : 3351-3357. 1995.

13) National Research Council. Nutrient Requirements of Poultry. 9th rev. ed. National Academy Press. Washington, D. C. 1994.

14) Page TG, Southern LL, Ward TL, Thompson DL. Effect of chromium picolinate on growth and serum and carcass traits of growing-finishing pigs. J. Anim. Sci., 71 : 656-662. 1993
15) Steele NC, Rosebrough RW. Trivalent chromium and nicotinic acid supplementation for the turkey poult. Poult. Sci., 58 : 983-984. 1979.

16) The Phamaceutical Society of Japan. Standard methods of analysis for hygenic chemists. 585587. Kanehara Co. Press. Tokyo. 1990.

17) Ward TL, Southern LL, Boleman SL. Effect of dietary chromium picolinate on growth, nitrogen balance and body composition of growing broiler chicks. Poult. Sci., 72 (suppl. 1) : 37. 1993.

\section{ブロイラーの成長掞よび体脂肪に及ぼすピコリン酸クロムと 酵母クロムの影響}

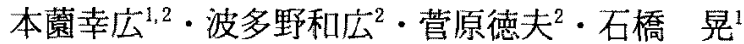 \\ 1 新潟大学大学院自然科学研究科, 新潟市 $950-2102$ \\ ${ }^{2}$ 日清製粉(株)那須研究所，枋木県西那須野町 329-2763
}

ブロイラー雛に 2 種類の有機クロム,ピコリン酸クロムおよび酵母クロムを給与した場合の発育およ

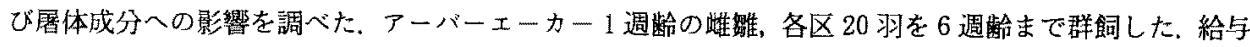

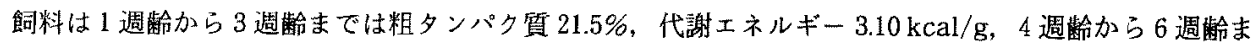
では粗タンパク質 $18.3 \%$ ，代謝エネルギー $3.20 \mathrm{kcal} / \mathrm{g}$ の基礎飼料を用い，ピコリン酸クロムおよび酵母

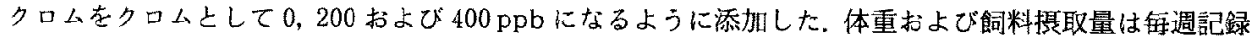
した，試験終了時に屠殺して，腹䏶内脂肪と皮なしの胸肉拉よび皮付きのむも肉の粗脂肪含量，粗タン パク質含量，水分含量を測定した，クロム添加区では飼料摄取量执よび增体重と香に低下する傾向がみ られ，特に酵母クロムの添加区 $(400 \mathrm{ppb})$ で増体重が有意に低下した，また，ピコリン酸クロムの添加

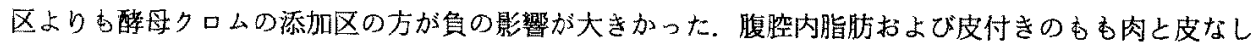

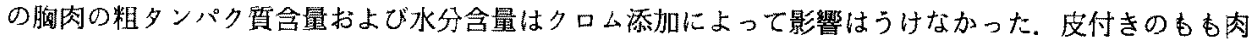
の粗脂肪含䁷はクロム添加の影響を受けなかったが，皮なしの胸闪の粗脂肪含量では飼料中のクロム含 量が増加するにつれ低下した。

日畜会報，69(3) : 247-252，1998 